\title{
Modeling of Sea Surface Temperature through Fitting Linear Model with Interaction
}

\section{Pemodelan Suhu Permukaan Laut melalui Model Linier Fitting dengan Interaksi}

\author{
Miftahuddin $^{1 *}$, Wanda Sri Noviana ${ }^{2}$
}

\begin{abstract}
Sea surface temperature (SST) is one of the attributes of the world climate system and global warming. The relationship between SST and other climate parameters can be represented in a linearity approach. Through this approach, SST variability shows monthly and yearly effects. Information on these two time effects is important for knowing the period of peak effect as well as other statistical measures in the linear fitting model. The models used include transformation and without covariate transformation, interaction and without covariate interaction, and with centering and with the addition of time covariates in the model. The linear fitting model chosen as the basis for construction is a model with a combination effect of covariate interaction and transformation giving an increase in the magnitude of multiple R2 $(56.62 \%)$ and adjusted R2 (56.13\%) respectively $0.31 \%$ and $0.43 \%$. This indicates that the time covariate has a very strong significant effect on the model compared to the continuous covariate. In general, the model has a statistical significance of p-value $<2.2 \mathrm{e}-16$, as well as for the time covariate. However, because the model has an autocorrelation and a large AIC value, this effect is removed by means of an autoregressive moving average. The obtained linear fitting model for SST data is the model with AIC 403.2987.
\end{abstract}

Keywords: Linear Fitting Model, Interaction and Transformation ff Covariates, $R^{2}$, AIC.

\begin{abstract}
Abstrak
Sea surface temperature (SST) merupakan salah satu atribut dari sistem iklim dunia dan pemanasan global. Hubungan antara SST dan parameter iklim lainnya dapat direpresentasikan dalam pendekatan linieritas. Melalui pendekatan ini, varibilitas SST menunjukkan adanya efek bulanan dan tahunan. Informasi kedua efek waktu tersebut adalah penting untuk mengetahui periode dari puncak efek serta ukuran statistik lainnya dalam model linier fitting. Model yang digunakan meliputi transformasi dan tanpa transformasi kovariat, interaksi dan tanpa interaksi kovariat, dan dengan centering serta dengan penambahan kovariat waktu dalam model. Model linier fitting terpilih menjadi dasar konstruksi adalah model dengan efek kombinasi interaksi kovariat dan transformasi memberikan kenaikan besaran multiple $\mathrm{R}^{2}(56.62 \%)$ dan adjusted $\mathrm{R}^{2}(56.13 \%)$ masing-masing sebesar $0.31 \%$ dan $0.43 \%$. Hal ini menunjukkan bahwa kovariat waktu memiliki efek signifikansi sangat kuat pada model dibandingkan dengan kovariat kontinu. Secara umum, model memiliki siginifikasi statistic $p$-value $<2.2 \mathrm{e}-16$, demikian pula untuk kovariat waktu. Akan tetapi karena model tersebut memiliki autokorelasi dan nilai AIC yang besar maka dilakukan penghilangan efek ini melalui autoregressive moving average. Diperoleh model linier fitting yang sesuai untuk data SST adalah model dengan AIC 403.2987.
\end{abstract}

Kata kunci: Model Linier Fitting, Interaksi dan Transformasi Kovariat, ${ }^{2}$, AIC.

*Jurusan Statistika, FMIPA Universitas Syiah Kuala, Banda Aceh 23111, Indonesial Email:miftah@unsyiah.ac.id ${ }^{l}$, novianawanda8@gmail.com ${ }^{2}$

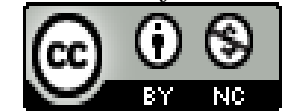

This work is licensed under a Creative Commons Attribution-NonCommercial 4.0 International License 


\section{Jurnal Matematika, Statistika \& Komputasi Miftahuddin, Wanda Sri Noviana}

\section{Pendahuluan}

Salah satu parameter penting dalam sistem iklim dunia dan indikator dari pemanasan global adalah suhu permukaan laut atau lebih dikenal dengan sea surface temperature (SST). Laut merupakan bagian bumi yang termasuk dalam $70.9 \%$ dan sisanya adalah daratan. Dengan laut terluas adalah samudera Pasifik (64 million square miles) dan samudera Atlantik (41.1 msm) serta Hindia $(28 \mathrm{msm})$ yang masing-masing kedua dan ketiga laut terluas. Data SST dapat menjadi indikator esensial untuk mengetahui variabilitas iklim bumi [2,3,4,5,9,11]. Indikator tersebut seperti adanya gejala El Nino dan La Nina di Samudera Pasifik yang berefek pada musim kemarau dan penghujan di wilayah sekitarnya termasuk Indonesia.

Data SST tergolong memiliki struktur yang kompleks seperti data hilang (missing value) yang direpresentasikan dengan adanya gap, dimana panjang gap memiliki keragaman antar buoys.

\section{Metode Penelitian}

Dalam penelitian ini, data SST dimodelkan sebagai kombinasi linear dari tiga parameter iklim dan dua kovariat waktu. Parameter-parameter ini adalah: suhu udara, kelembaban relatif, dan curah hujan dalam efek bulanan dan tahunan. Kompleksitas hubungan antara respon dan kovariat menjadi tantangan dalam memodelkan data SST yang dinamis. Perlakuan terhadap model yang dikonstruksi adalah tanpa transformasi dan dengan transformasi kovariat, tanpa interaksi dan dengan interaksi kovariat, serta campuran kedua perlakuan tersebut.

\subsection{Fitting model linier}

Dalam pemodelan awal, data SST observasi merupakan data harian, dengan mempertimbangkan asumsi linear dari data $\left(x_{\mathrm{i}}, y_{\mathrm{i}}\right), i=1,2, \ldots, n$ dimana sumbu axis untuk kovariat $x_{\mathrm{i}}$ dan $y_{\mathrm{i}}$ merupakan variabel respon kontinu. Hubungan antara variabel $\mathrm{X}$ dan $\mathrm{Y}$ dapat ditulis sebagai model linier dalam bentuk matriks sebagai:

$$
\boldsymbol{Y}=\boldsymbol{X} \boldsymbol{\beta}+\boldsymbol{\varepsilon}
$$

dimana $\boldsymbol{Y}=\left(\mathrm{y}_{1}, \ldots, \mathrm{y}_{\mathrm{n}}\right)^{\mathrm{T}} \in \mathrm{R}^{\mathrm{n}}$ adalah vektor kolom dari variabel respon, $\boldsymbol{\beta}=\left(\beta_{0}, \beta_{1}, \ldots, \beta_{\mathrm{p}}\right)^{\mathrm{T}} \epsilon$ $\mathrm{R}^{\mathrm{p}+1}$ adalah vector kolom dari parameter yang tidak diketahui, $\boldsymbol{X} \in \mathrm{R}^{\mathrm{nx}(\mathrm{p}+1)}$ adalah matriks dengan $n$ baris dan $p+1$ kolom dari sebuah himpuanan dari $p$ covariates $X_{0}, X_{1}, \ldots, X_{\mathrm{p}}$ dari panjang $n$ termasuk intercept dan errors $\varepsilon$ yang diasumsikan independent and identically distributed (i.i.d), i.e. normal variabel random $\boldsymbol{\varepsilon} \sim N\left(\mathbf{0}_{\mathbf{n}}, \sigma^{2} \mathbf{I}_{\mathbf{n}}\right)$, dimana $\boldsymbol{\varepsilon}=\left(\varepsilon_{1}, \ldots, \varepsilon_{\mathrm{n}}\right)^{\mathrm{T}}$ adalah vektor kolom dari error dan $\mathbf{I}_{\mathrm{n}}$ adalah matriks identitas.

Kovariat dapat diberikan berupa nilai-nilai kuantitatif, kualitatif, transformasi, interaksi antara kovariat, dan variabel yang mewakili faktor nominal [1,6,7,8,10,12]. Ekspektasi bersyarat menggambarkan hubungan linier atau fungsional dari parameter model,

atau

$$
E[\mathrm{Y} \mid \mathrm{X}]=\sum_{\mathrm{j}=0} \beta_{j} \mathrm{X}_{j}
$$

$$
\mu_{\mathrm{i}}=E\left[\mathrm{Y} \mid \mathrm{X}_{\mathrm{i}}\right]=f\left(\mathrm{X}_{\mathrm{i}}\right), i=1, \ldots, n
$$

\subsection{Model dengan interaksi}

Asumsi additivity dengan model interaksi sebagai:

$$
\mu_{\mathrm{ij}}=\mu+\alpha_{\mathrm{i}}+\beta_{\mathrm{j}}+(\alpha \beta)_{\mathrm{ij}}
$$

dimana $\mu$ adalah konstan, $\alpha_{\mathrm{i}}$ dan $\beta_{\mathrm{j}}$ adalah efek utama, dan $(\alpha \beta)_{\mathrm{ij}}$ adalah efek interaksi.

\subsection{Data SST}

Dalam kajian ini digunakan pelampung (buoy moored) untuk real-time data SST harian yang berasal dari Tropical Atmosphere Ocean (TAO) yaitu pelampung yang ditambatkan di samudera Hindia pada posisi $1.5 \mathrm{~N} 90 \mathrm{E}$, kedalaman $1 \mathrm{~m}$, dari periode antara 1 Januari 2006 sampai 8 Juni 2012. Dataset SST lengkap terdiri dari 2066 pengamatan harian dengan variabel respon SST 


\section{Jurnal Matematika, Statistika \& Komputasi \\ Miftahuddin, Wanda Sri Noviana}

$\left({ }^{0} \mathrm{C}\right)$ dari pukul 00.00 sampai 12.00 pm waktu GMT, dan diberikan kovariat, yaitu suhu udara $\left({ }^{0} \mathrm{C}\right)$, kelembaban relatif $(\%)$, kovariat memiliki rata-rata dengan catatan waktu yang sama pada pukul 07.00 WIB, 13.00 WIB dan 18.00 WIB, curah hujan $(\mathrm{mm})$ selama tiga-jam periode, faktor musiman dan tahunan.

Untuk menunjukkan pentingnya kovariat waktu dalam model linier kita menggunakan model dari fungsi $f$ (.) direpresentasikan oleh model dengan tiga kovariat kontinu dan dua kovariat waktu, yaitu bulan dan tahun. Kami berasumsi bahwa tiga kovariat kontinu yang berhubungan linier dengan SST, yaitu hubungan akan sama untuk semua tingkat kovariat waktu dan tanpa interaksi antara kovariat adalah sebagai berikut,

$$
\mathrm{SST}_{\mathrm{i}}=\beta_{0}+\beta_{1} \text { Temp }_{\mathrm{i}}+\beta_{2} \text { Humd }_{\mathrm{i}}+\beta_{3} \text { Rain }_{\mathrm{i}}+\eta_{\mathrm{k}} \text { Month }_{\mathrm{i}}+\gamma_{\mathrm{l}} \text { Year }_{\mathrm{i}}+\varepsilon_{\mathrm{i}}
$$

untuk $k=1, \ldots, 12 ; l=1,2, \ldots, 6$, dan $i=1, \ldots, n$, dimana $\eta$ dan $\gamma$ adalah vektor parameter dari kovariat waktu untuk masing-masing month and year. Sedangkan Temp adalah variabel temperatur udara (derajat Celcius), Humd adalah variabel kelembaban relatif dalam (persentase), dan Rain adalah variabel curah hujan dalam ( $\mathrm{mm}$ ). Model unrestricted dimana model memiliki efek musiman $\eta_{\mathrm{m}}$ dan efek tahunan $\gamma_{1}$ adalah restricted to 0 . Kami mengevaluasi beberapa model dengan urutan yang berbeda termasuk kovariat waktu dalam model.

\section{Hasil dan Pembahasan}

\subsection{Model linier fitting tanpa transformasi kovariat}

Model awal (M1) yang dibangun tanpa interaksi dan tanpa transformasi kovariat yaitu, M1: SST $=\beta_{0}+\beta_{1}$ Temp $+\eta_{\mathrm{k}}$ Month $+\gamma_{1}$ Year $+\beta_{2}$ Humd $+\beta_{3}$ RAIN $+\varepsilon$

Tabel 3.1. Anova dari model M1

\begin{tabular}{|clllll|}
\hline & df & SS & MS & F-value & $\operatorname{Pr}(>\mathrm{F})$ \\
\hline Temperatur & 1 & 83.331 & 83.331 & 581.2248 & $<2 \mathrm{e}-16^{* * *}$ \\
Month & 11 & 236.830 & 21.530 & 150.1698 & $<2 \mathrm{e}-16^{* * *}$ \\
Year & 6 & 57.463 & 9.577 & 66.7999 & $<2 \mathrm{e}-16^{* * *}$ \\
Kelembaban & 1 & 0.183 & 0.183 & 1.2750 & 0.2590 \\
Curah hujan & 1 & 0.002 & 0.002 & 0.0132 & 0.9087 \\
Residuals & 2045 & 293.193 & 0.143 & & \\
\hline
\end{tabular}

Dari Tabel 3.1 untuk model M1 diketahui bahwa untuk kovariat kontinu menunjukkan bahwa kelembaban dan curah hujan tidak memberikan efek signifikan. Model fitting mencapai $56,31 \%$ (nilai $\mathrm{R}^{2}$ ).

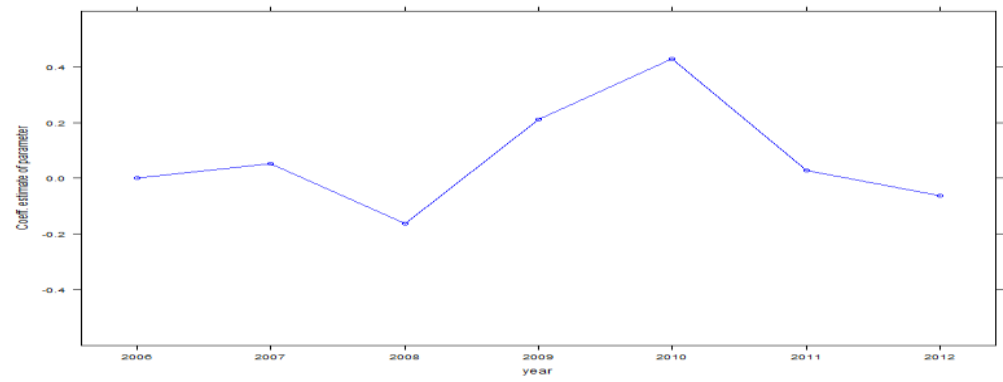

Gambar 3.1. Efek tahunan (annual effect) dari model M1

Gambar 3.1 efek tahunan dari model M1 menunjukkan kenaikan lambat "slightly increase" efek tahunan terjadi dari tahun 2006 ke 2007, menurun secara cepat "rapid decrease" terjadi dari tahun 2007 ke 2008, dan naik secara cepat "rapid increase" terjadi dari 2008 ke 2010. Selanjutnya menurun tajam hingga tahun 2011 dan menurun secara lambat dari tahun $2011 \mathrm{ke}$ tahun 2012. Secara umum, dari 2007 ke 2008 memberikan efek nonpositif demikian pula dari 


\section{Jurnal Matematika, Statistika \& Komputasi}

Miftahuddin, Wanda Sri Noviana

tahun 2011 ke tahun 2012. Sedangkan dari tahun 2006 ke 2007, dari tahun 2008 ke tahun 2011 memberikan efek positif.

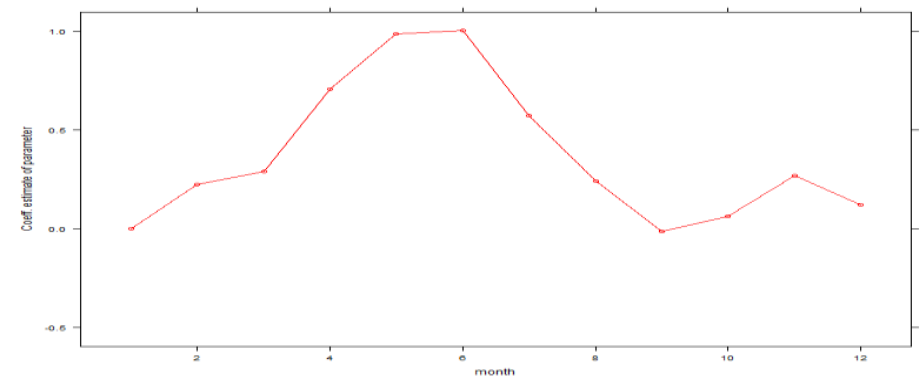

Gambar 3.2. Efek bulanan (seasonal effect) dari model M1

Gambar 3.2 efek bulanan (seasonal effect) dari model M1 menunjukkan trend naik terjadi dari bulan Januari hingga Juni dan trend menurun dari bulan Juni hingga September. Selanjutnya, trend terus menaik kembali hingga November dan berikutnya menurun hingga Desember. Puncak efek bulanan tertinggi terjadi pada bulan Juni dan terendah pada bulan September.

Untuk bulan Januari ke bulan Februari terjadi kenaikan cepat (rapid increase), dan naik secara lambat (slightly increase) dari bulan Februari ke bulan Maret. Selanjutnya, kenaikan cepat terjadi kembali dari bulan Maret ke bulan Mei. Naik secara lambat juga terjadi lagi dari bulan Mei ke bulan Juni. Akan tetapi, penurunan cepat (rapid decrease) terjadi dari bulan Juni ke bulan September. Kenaikan secara lambat terjadi pada bulan September ke bulan Oktober dan kenaikan cepat terjadi dari bulan Oktober ke bulan November. Selanjutnya penurunan kembali terjadi dari bulan November hingga Desember.

\subsection{Model linier fitting dengan transformasi kovariat}

Model kedua (M2) dengan transformasi yang digunakan adalah Rain $=\log (\mathrm{RAIN}+0.01)$ sedangkan model konstruksi M2: SST $=\beta_{0}+\beta_{1}$ Temp $+\eta_{\mathrm{k}}$ Month $+\gamma_{1}$ Year $+\beta_{2}$ Humd $+\beta_{3}$ Rain $+\boldsymbol{\varepsilon}$

Tabel 3.2. Anova dari model M2

\begin{tabular}{|clllll|}
\hline & df & SS & MS & F-value & $\operatorname{Pr}(>\mathrm{F})$ \\
\hline Temperatur & 1 & 83.331 & 83.331 & 581.322 & $<2 \mathrm{e}-16^{* * *}$ \\
Month & 11 & 236.830 & 21.530 & 150.195 & $<2 \mathrm{e}-16^{* * *}$ \\
Year & 6 & 57.463 & 9.577 & 66.811 & $<2 \mathrm{e}-16^{* * *}$ \\
Kelembaban & 1 & 0.183 & 0.183 & 1.275 & 0.2589 \\
Curah hujan & 1 & 0.051 & 0.051 & 0.355 & 0.5512 \\
Residuals & 2045 & 293.144 & 0.143 & & \\
\hline
\end{tabular}

Dari Tabel 3.2 untuk model M2 diketahui kelembaban dan curah hujan tidak berefek signifikan. Pada transformasi kovariat (curah hujan) tidak merubah besaran fitting pada model untuk multiple $\mathrm{R}^{2}$. Akan tetapi, memberi perubahan pada adjusted $\mathrm{R}^{2}$ sebesar $0,01 \%$. Hal ini disebabkan efek kovariat kontinu sangat kecil dibandingkan dengan efek kovariat waktu dalam model linier fitting (lihat model M1 dan M2).

\subsection{Model linier fitting dengan interaksi kovariat, tanpa transformasi}

Model ketiga (M3) adalah model dengan interaksi kovariat tanpa transformasi, M3: SST $=\beta_{0}+\beta_{1}$ Temp $+\eta_{\mathrm{k}}$ Month $+\gamma_{1}$ Year $+\beta_{2}$ Humd $+\beta_{3}$ Rain $+\beta_{4}$ Temp*Humd $+\beta_{5}$ Temp*Rain $+\beta_{6}$ Humd $*$ Rain $+\boldsymbol{\varepsilon}$ 


\section{Jurnal Matematika, Statistika \& Komputasi \\ Miftahuddin, Wanda Sri Noviana}

Tabel 3.3. Anova dari model M3

\begin{tabular}{|clllll|}
\hline & df & SS & MS & F-value & $\operatorname{Pr}(>\mathrm{F})$ \\
\hline Temperatur & 1 & 83.331 & 83.331 & 581.211 & $<2 \mathrm{e}-16 * * *$ \\
Month & 11 & 236.830 & 21.530 & 150.166 & $<2 \mathrm{e}-16$ *** \\
Year & 6 & 57.463 & 9.577 & 66.7984 & $<2 \mathrm{e}-16 * * *$ \\
Kelembaban & 1 & 0.183 & 0.183 & 1.2750 & 0.2590 \\
Curah hujan & 1 & 0.002 & 0.002 & 0.0132 & 0.9087 \\
Temp:Humd & 1 & 0.142 & 0.142 & 0.9873 & 0.3205 \\
Temp:Rainfall & 1 & 0.000 & 0.000 & 0.0011 & 0.9738 \\
Humd:Rainfall & 1 & 0.282 & 0.282 & 1.9636 & 0.1613 \\
Residuals & 2042 & 292.770 & 0.143 & & \\
\hline
\end{tabular}

Dari Tabel 3.3, model M3 diketahui bahwa kelembaban, curah hujan dan semua interaksi kontinu kovariat tidak berefek signifikan. Efek interaksi model dengan tanpa transformasi pada buoy memberi kenaikan multiple $\mathrm{R}^{2}$ sebesar $0,06 \%$. Meskipun besaran adjusted $\mathrm{R}^{2}$ adalah tetap $55,88 \%$ (lihat nilai $\mathrm{R}^{2}$ sebelum dan setelah interaksi pada model $\mathrm{M} 2$ dan $\mathrm{M} 3$ ).

\subsection{Model linier fitting dengan interaksi kovariat dan transformasi}

Model keempat (M4) adalah model dengan interaksi kovariat dan transformasi

M4: SST $=\beta_{0}+\beta_{1}$ Temp $+\eta_{\mathrm{k}}$ Month $+\gamma_{1}$ Year $+\beta_{2}$ Humd $+\beta_{3}$ Rain $+\beta_{4}$ Temp*Humd $+\beta_{5}$ Temp*Rain $+\beta_{6}$ Humd*Rain $+\boldsymbol{\varepsilon}$

Tabel 3.4. Anova dari model M4

\begin{tabular}{|clllll|}
\hline & df & SS & MS & F-value & $\operatorname{Pr}(>\mathrm{F})$ \\
\hline Temperatur & 1 & 83.331 & 83.331 & 584.5832 & $<2 \mathrm{e}-16^{* * *}$ \\
Month & 11 & 236.830 & 21.530 & 151.0375 & $<2 \mathrm{e}-16^{* * *}$ \\
Year & 6 & 57.463 & 9.577 & 67.1859 & $<2 \mathrm{e}-16^{* * *}$ \\
Kelembaban & 1 & 0.183 & 0.183 & 1.2824 & 0.25758 \\
Curah hujan & 1 & 0.051 & 0.051 & 0.3574 & 0.55004 \\
Temp:Humd & 1 & 0.152 & 0.152 & 1.0655 & 0.30208 \\
Temp:Rainfall & 1 & 0.053 & 0.053 & 0.3734 & 0.54122 \\
Humd:Rainfall & 1 & 1.858 & 1.858 & 13.0334 & $0.00031^{* * *}$ \\
Residuals & 2042 & 291.081 & 0.143 & & \\
\hline
\end{tabular}

Dari Tabel 3.4 anova dari model M4 menunjukkan bahwa kelembaban, curah hujan dan interaksi kontinu kovariat tidak berefek signifikan, kecuali interaksi kelembaban dan curah hujan memberikan efek signifikan sangat kuat seperti temperatur, Month dan Year. Efek kombinasi antara interaksi dan transformasi memberikan perubahan besaran multiple $\mathrm{R}^{2}$ dan adjusted $\mathrm{R}^{2}$ masing-masing sebesar $0,31 \%$ dan $0,43 \%$ (lihat nilai $\mathrm{R}^{2}$ pada model M1 dan M4).

\subsection{Model linier fitting dengan interaksi kovariat, tanpa transformasi, dan centering}

Model kelima (M5) adalah model dengan interaksi kovariat, tanpa transformasi dan centering

M5: SST $=\beta_{0}+\beta_{1}$ Temp $+\eta_{\mathrm{k}}$ Month $+\gamma_{1}$ Year $+\beta_{2}$ Humd $+\beta_{3}$ Rain $+\beta_{4}$ Temp*Humd $+\beta_{5}$ Temp*Rain $+\beta_{6}$ Humd*Rain $+\boldsymbol{\varepsilon}$

Tabel 3.5. Anova dari M5 model

\begin{tabular}{|clllll|}
\hline & df & SS & MS & F-value & $\operatorname{Pr}(>\mathrm{F})$ \\
\hline Temperatur & 1 & 83.331 & 83.331 & 581.2111 & $<2 \mathrm{e}-16 * * *$ \\
Month & 11 & 236.830 & 21.530 & 150.1663 & $<2 \mathrm{e}-16 * * *$ \\
Year & 6 & 57.463 & 9.577 & 66.7984 & $<2 \mathrm{e}-16 * * *$ \\
\hline
\end{tabular}




\section{Jurnal Matematika, Statistika \& Komputasi}

Miftahuddin, Wanda Sri Noviana

\begin{tabular}{|clllll|}
\hline Kelembaban & 1 & 0.183 & 0.183 & 1.2750 & 0.2590 \\
Curah hujan & 1 & 0.009 & 0.009 & 0.0624 & 0.8027 \\
Temp:Humd (TH) & 1 & 0.134 & 0.134 & 0.9326 & 0.3343 \\
Temp:Rainfall (TR) & 1 & 0.001 & 0.001 & 0.0065 & 0.9356 \\
Humd:Rainfall (HR) & 1 & 0.282 & 0.282 & 1.9636 & 0.1613 \\
Residuals & 2042 & 292.770 & 0.143 & & \\
\hline
\end{tabular}

Dari Tabel 3.5 anova dari model M5 menunjukkan bahwa kelembaban, curah hujan dan semua interaksi kontinu kovariat tidak berefek signifikan dari perlakuan tanpa transformasi dan centering. Efek centering dalam interksi model tidak merubah nilai $\mathrm{R}^{2}$. Hal ini disebabkan oleh adanya dominasi efek waktu kovariat lebih besar dibandingkan efek kontinu kovariat (lihat nilai $\mathrm{R}^{2}$ pada model M3 dan M5).

\subsection{Model linier fitting dengan interaksi kovariat, dengan transformasi, dan centering} Model M6 adalah analog konstruksi model M5, hanya dengan transformasi.

Tabel 3.6. Anova dari model M6

\begin{tabular}{|clllcl|}
\hline & df & SS & MS & F-value & $\operatorname{Pr}(>\mathrm{F})$ \\
\hline Temperatur & 1 & 83.331 & 83.331 & 582.8757 & $<2 \mathrm{e}-16 * * *$ \\
Month & 11 & 236.830 & 21.530 & 150.5964 & $<2 \mathrm{e}-16^{* * *}$ \\
Year & 6 & 57.463 & 9.577 & 66.9897 & $<2 \mathrm{e}-16 * * *$ \\
Kelembaban & 1 & 0.183 & 0.183 & 1.2787 & 0.2583 \\
Curah hujan & 1 & 0.002 & 0.002 & 0.0111 & 0.9162 \\
Temp:Humidity & 1 & 0.134 & 0.134 & 0.9353 & 0.3336 \\
Temp:Rainfall & 1 & 0.008 & 0.008 & 0.0538 & 0.8166 \\
Humd:Rainfall & 1 & 1.118 & 1.118 & 7.8217 & $0.0052^{* *}$ \\
Residuals & 2042 & 291.934 & 0.143 & & \\
\hline
\end{tabular}

Dari Tabel 3.6 anova dari model M6 menunjukkan bahwa kelembaban, curah hujan dan beberapa interaksi kontinu kovariat tidak berefek signifikan, kecuali interaksi kelembaban dan curah hujan memberikan efek signifikan kuat. Hal ini menunjukkan pula bahwa dari perlakuan interaksi dengan transformasi lebih berefek dibandingan hanya dengan centering tanpa transformasi. Perlakuan interaksi kovariat, transformasi kontinu kovariat dan centering dalam interksi model memberikan efek terhadap nilai $\mathrm{R}^{2}$ yaitu multiple $\mathrm{R}^{2}$ dan adjusted $\mathrm{R}^{2}$ masingmasing adalah sebesar $0,18 \%$ dan $0,12 \%$ (lihat besaran nilai $\mathrm{R}^{2}$ pada M1 dan M6 model).

Tabel 3.7. Statistics inferensi dari model linier fitting untuk data SST

\begin{tabular}{|llllllll|}
\hline \multirow{2}{*}{ Model } & $\begin{array}{l}\text { Residual } \\
\text { SE }\end{array}$ & \multirow{2}{*}{ df } & $\begin{array}{l}\text { Multiple } \\
\mathrm{R}^{2}\end{array}$ & $\begin{array}{l}\text { Adjusted } \\
\mathrm{R}^{2}\end{array}$ & F-statistic & p-value & \multirow{2}{*}{ AIC } \\
\hline M1 & 0.3786 & 2045 & $56.31 \%$ & $55.88 \%$ & $131.8(\mathrm{df}=20 \& 2045)$ & $<2.2 \mathrm{e}-16$ & 1864.176 \\
M2 & 0.3786 & 2045 & $56.31 \%$ & $55.89 \%$ & $131.8(\mathrm{df}=20 \& 2045)$ & $<2.2 \mathrm{e}-16$ & 1872.767 \\
M3 & 0.3786 & 2042 & $56.37 \%$ & $55.88 \%$ & $114.7(\mathrm{df}=23 \& 2042)$ & $<2.2 \mathrm{e}-16$ & 1876.128 \\
M4 & 0.3776 & 2042 & $56.62 \%$ & $56.13 \%$ & $115.9(\mathrm{df}=23 \& 2042)$ & $<2.2 \mathrm{e}-16$ & 1864.176 \\
M5 & 0.3786 & 2042 & $56.37 \%$ & $55.88 \%$ & $114.7(\mathrm{df}=23 \& 2042)$ & $<2.2 \mathrm{e}-16$ & 1876.128 \\
M6 & 0.3781 & 2042 & $56.49 \%$ & $56.00 \%$ & $115.3(\mathrm{df}=23 \& 2042)$ & $<2.2 \mathrm{e}-16$ & 1870.220 \\
M7 & 0.3657 & 1994 & $60.26 \%$ & $58.85 \%$ & $42.59(\mathrm{df}=71 \& 1994)$ & $<2.2 \mathrm{e}-16$ & 1779.054 \\
M8 & 0.3660 & 1994 & $60.20 \%$ & $58.78 \%$ & $42.48(\mathrm{df}=71 \& 1994)$ & $<2.2 \mathrm{e}-16$ & 1782.316 \\
\hline
\end{tabular}

Dari Tabel 3.7 statistics inferens menunjukkan model M1-M2 tanpa interaksi dan model M3 -M6 dengan interaksi memiliki nilai residual SE yang serupa, kecuali model M4. Kesemua model (M1-M8) memiliki nilai $p$-value yang sama <2.2e-16. Akan tetapi, semua model tersebut memilik i nilai AIC yang besar sehingga perlu dilakukan perbaikan fitting. 


\section{Jurnal Matematika, Statistika E Komputasi \\ Miftahuddin, Wanda Sri Noviana}

Tabel 3.8. Residuals dari Model yang dikonstruksi

\begin{tabular}{|llllll|}
\hline Model & Min & Q1 & Median & Q3 & Max \\
\hline M1 & -1.13813 & -0.25809 & -0.00793 & 0.25195 & 1.29845 \\
M2 & -1.13401 & -0.25838 & -0.00665 & 0.25000 & 1.30300 \\
M3 & -1.14030 & -0.25831 & -0.01194 & 0.24930 & 1.29932 \\
M4 & -1.11683 & -0.26354 & -0.01615 & 0.24835 & 1.29569 \\
M5 & -1.14030 & -0.25831 & -0.01194 & 0.24930 & 1.29932 \\
M6 & -1.14305 & -0.25849 & -0.01299 & 0.25037 & 1.29253 \\
M7 & -1.10256 & -0.24663 & -0.01694 & 0.24173 & 1.25497 \\
M8 & -1.09797 & -0.24288 & -0.01264 & 0.23747 & 1.29026 \\
\hline
\end{tabular}

Tabel 3.8 residuals di atas menunjukkan bahwa similaritas untuk nilai-nilai residual dari mo del M1-M8 seperti nilai minimum, median, maximum, kuartil ke-1 dan 3.

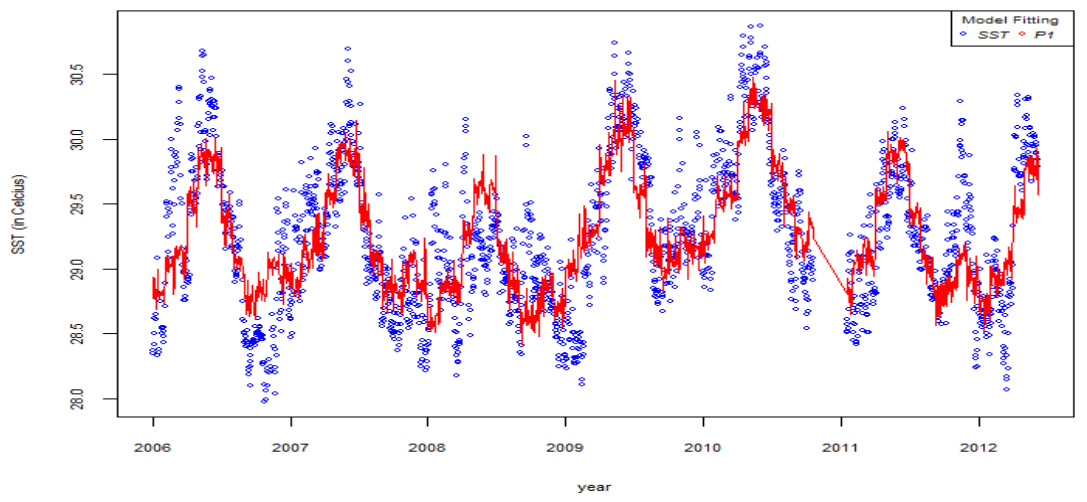

Gambar 3.3. M4 model linier fitting dari data SST

Selanjutnya interaksi antara kovariat kontinu dengan kovariat faktor dikombinasikan dalam model linier, dimana perlakuan dengan dan tanpa transformasi. Dari perlakuan-perlakuan ini diketahui bahwa terjadi kenaikan nilai $\mathrm{R}^{2}$ dan ajusted $\mathrm{R}^{2}$, masing-masing dari $56,62 \%$ (M4) ke $60,26 \%$ dan dari 56,13\% ke 58,85\% (M7). Akan tetapi, efek kombinasi perlakuan ini menyebabkan perubahan pola efek tahunan dan efek bulanan, sehingga kombinasi interaksi ini dapat diabaikan dalam model fitting. Meskipun dengan dan tanpa transformasi sebagaimana pada model M7 dan M8 memberikan signifikansi antara beberapa interaksi faktor dari kovariat waktu dan kovariat kontinu (Tabel 15 dan Tabel 16).

\subsection{Dengan transformasi dan interaksi}

Model konstruksi M7: SST $=($ Temp+Humd+Rain $) *$ Month $+($ Temp+Humd+Rain $) *$ Year

Tabel 3.9. Anova dari model M7

\begin{tabular}{|clllll|}
\hline & df & SS & MS & F-value & $\operatorname{Pr}(>\mathrm{F})$ \\
\hline Temperatur & 1 & 83.331 & 83.331 & 622.1454 & $<2 \mathrm{e}-16 * * *$ \\
Kelembaban & 1 & 0.031 & 0.031 & 0.2306 & 0.6311 \\
Curah hujan & 1 & 0.564 & 0.564 & 4.2182 & $0.0401 *$ \\
Month & 11 & 236.681 & 21.516 & 160.8995 & $<2 \mathrm{e}-16 * * *$ \\
Year & 6 & 57.251 & 9.542 & 71.3533 & $<2 \mathrm{e}-16 * * *$ \\
Temp:Month & 11 & 2.898 & 0.263 & 1.9702 & $0.0276 *$ \\
Humd:Month & 11 & 8.580 & 0.780 & 5.8326 & $2.256 \mathrm{e}-09 * * *$ \\
RAIN:Month & 11 & 3.222 & 0.293 & 2.1903 & $0.0127 *$ \\
Temp:Year & 6 & 9.263 & 1.544 & 11.5448 & $9.737 \mathrm{e}-13 * * *$ \\
Humd:Year & 6 & 1.670 & 0.278 & 2.0811 & 0.0525. \\
\hline
\end{tabular}




\section{Jurnal Matematika, Statistika E Komputasi}

Miftahuddin, Wanda Sri Noviana

\begin{tabular}{clllll}
\hline RAIN:Year & 6 & 0.862 & 0.144 & 1.0746 & 0.3754 \\
Residuals & 1994 & 266.650 & 0.134 & & \\
\hline
\end{tabular}

Dari Tabel 3.9 anova dari model M7 menunjukkan bahwa signifikansi efek, kecuali untuk kelembaban dan interaksi antara variabel curah hujan dan Year.

\subsection{Tanpa transformasi dan dengan interaksi}

Model yang dikonstrksi M8: analog model M7 hanya tanpa transformasi.

Tabel 3. 10. Anova dari model M8

\begin{tabular}{|clllcl|}
\hline & df & SS & MS & F-value & $\operatorname{Pr}(>\mathrm{F})$ \\
\hline Temperatur & 1 & 83.331 & 83.331 & 622.1623 & $<2 \mathrm{e}-16 * * *$ \\
Kelembaban & 1 & 0.031 & 0.031 & 0.2302 & 0.63141 \\
Curah hujan & 1 & 0.042 & 0.042 & 0.3118 & 0.57662 \\
Month & 11 & 237.068 & 21.552 & 160.9082 & $<2 \mathrm{e}-16 * * *$ \\
Year & 6 & 57.337 & 9.556 & 71.3483 & $<2 \mathrm{e}-16 * * *$ \\
Temp:Month & 11 & 2.918 & 0.265 & 1.9809 & $0.02663 *$ \\
Humd:Month & 11 & 8.583 & 0.780 & 5.8254 & $2.333 \mathrm{e}-09 * * *$ \\
RAIN:Month & 11 & 1.422 & 0.129 & 0.9653 & 0.47616 \\
Temp:Year & 6 & 9.333 & 1.555 & 11.6135 & $8.069 \mathrm{e}-13 * * *$ \\
Humd:Year & 6 & 1.569 & 0.262 & 1.9526 & 0.06918. \\
RAIN:Year & 6 & 2.297 & 0.383 & 2.8587 & $0.00894 * *$ \\
Residuals & 1994 & 267.071 & 0.134 & & \\
\hline
\end{tabular}

Berdasarkan hasil efek kombinasi interaksi antara kovariat kontinu dengan kovariat factor di atas, maka investigasi selanjutnya terhadap autokorelasi dalam model fitting.

Tabel 3. 11. AIC dari Struktur Model yang dikonstruksi

\begin{tabular}{|lll|}
\hline Model & Struktur & AIC \\
\hline M9 & SST = Temp + Month + Year + Humd + Rain & -1357.365 \\
M10 & SST= Temp + Month + Year + Humd + & -1313.447 \\
& Temp*Humd + Temp*Rain + Rain + Humd*Rain & \\
M11 & Analog M10 dengan transformasi & -1318.326 \\
M12 & Analog M10 tanpa transformasi & -755.2367 \\
M13 & Analog M10 dengan transformasi & -771.0071 \\
M14 & Analog M10 dengan transformasi & 556.4355 \\
M15 & Analog M10 dengan transformasi & 403.2987 \\
\hline
\end{tabular}

Residual pada within dan between group untuk kovariat waktu menjadi perhatian dalam fitting menggunakan model linier melalui struktur autokorelasi. Model 9-10 dikonstruksi melalui korelasi $\operatorname{ARMA}(\mathrm{p}=1, \mathrm{q}=1)$ dan model M11 dengan $\operatorname{ARMA}(\mathrm{p}=2, \mathrm{q}=2)$ menghasilkan nilai AIC negatif (lihat Tabel 3.11). Karena itu perbaikan terhadap fitting dilakukan dengan konstruksi autokorelasi melalui AR(1) pada model M12 dan M13 masing-masing tanpa dan dengan transformasi. Hasil yang diberikan adalah negatif dari setengah dari nilai AIC pada perlakukan model sebelumnya. Selanjutnya, kembali melalui pendekatan autokorelasi ARMA dengan formulasi 1| Month pada M14 dan M15 dan membeikan nilai AIC positif. Dalam kajian ini tidak ditampilkan matriks korelasi dari model.

Tabel 3. 12. GLS fit by REML dari Model yang Dikonstruksi

\begin{tabular}{|cllllll|}
\hline Model & AIC & BIC & Loglik & Parameter Est. & Df (total) & Residual \\
\hline M12 & -755.2367 & -609.0729 & 403.6184 & 0.88001 & 2066 & 2042 \\
M13 & -771.0071 & -624.8433 & 411.5035 & 0.87993 & 2066 & 2042 \\
\hline
\end{tabular}




\section{Jurnal Matematika, Statistika \& Komputasi}

\section{Miftahuddin, Wanda Sri Noviana}

\begin{tabular}{|lllllll|}
\hline M14 & 556.4355 & 702.5993 & -252.2178 & 0.71406 & 2066 & 2042 \\
M15 & 403.2987 & 549.4625 & -175.6493 & 0.78685 & 2066 & 2042 \\
\hline
\end{tabular}

Tabel 3.12 menunjukkan similar estimasi parameter dengan nilai AIC, BIC dan Loglik yang berbeda dari model M12-M15. Ke semua model memiliki total deg-rees of freedom $d f$ dan residual yang sama.

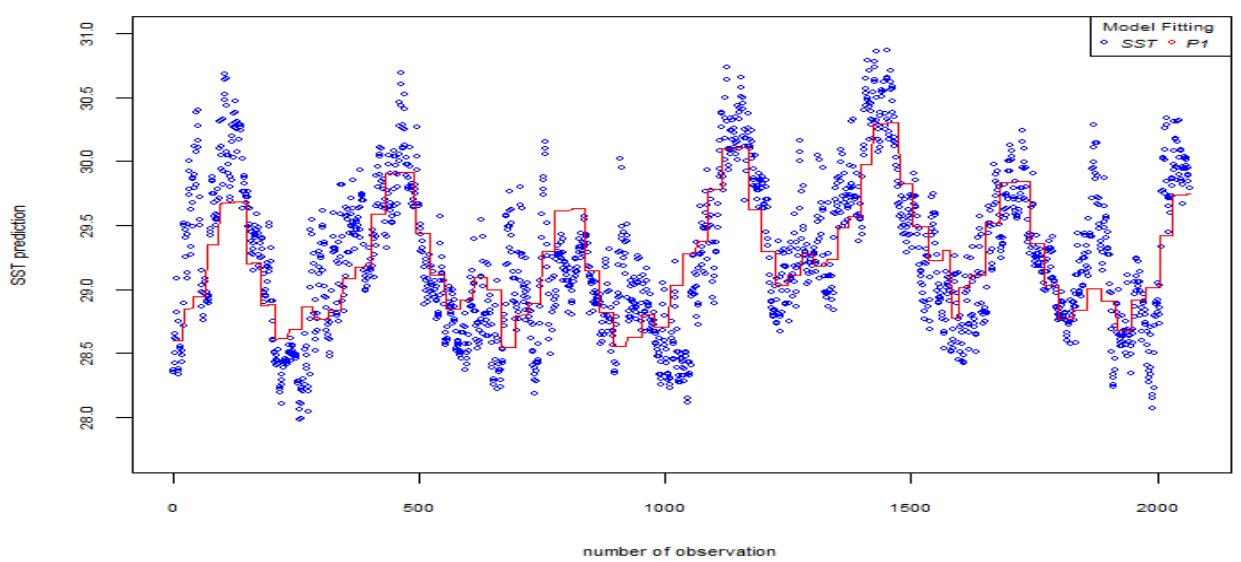

Gambar 3.4. Model M12 linier fitting untuk data SST

Tabel 3. 13. Standardized Residuals dari Model yang Dikonstruksi

\begin{tabular}{|lllllll|}
\hline Model & Min & Q1 & Median & Q3 & Max & Residual SE \\
\hline M12 & -2.90934 & -0.65371 & -0.04610 & 0.62098 & 3.41958 & 0.40596 \\
M13 & -2.89661 & -0.65760 & -0.04528 & 0.61766 & 3.47573 & 0.40552 \\
M14 & -3.50634 & -0.82194 & -0.03429 & 0.77083 & 4.22042 & 0.32457 \\
M15 & -3.53756 & -0.84165 & -0.03203 & 0.79993 & 4.34173 & 0.31872 \\
\hline
\end{tabular}

Berdasarkan Tabel 3.13 maka model M15 memiliki nilai residual SE terkecil dibandingkan dengan model yang dikonstruksi lainnya.

Dengan menggunakan model M12 dan M13 dan dengan koefisien korelasi antara Rho $=0,5$ - 0,9 diperoleh Tabel ANOVA sebagai berikut:

Tabel 3.14. Anova dari model M12 dan M13

\begin{tabular}{|cllllll|}
\hline & \multicolumn{3}{c}{ M12 } & \multicolumn{3}{c|}{ M13 } \\
\hline Parameter & numDF & F-value & p-value & numDF & F-value & p-value \\
Intercept & 1 & 742758.5 & $<.0001$ & 1 & 744814.7 & $<.0001$ \\
Temp & 1 & 20.0 & $<.0001$ & 1 & 20.1 & $<.0001$ \\
Month & 11 & 11.2 & $<.0001$ & 11 & 11.2 & $<.0001$ \\
Year & 6 & 33.3 & $<.0001$ & 6 & 33.4 & $<.0001$ \\
Humd & 1 & 1.2 & 0.2700 & 1 & 1.2 & 0.2697 \\
RAIN & 1 & 0.0 & 0.8382 & 1 & 0.0 & 0.8474 \\
Temp:Humd & 1 & 0.7 & 0.4006 & 1 & 0.7 & 0.4040 \\
Temp:RAIN & 1 & 0.1 & 0.7158 & 1 & 1.0 & 0.3206 \\
Humd:RAIN & 1 & 0.1 & 0.7527 & 1 & 2.5 & 0.1127 \\
\hline
\end{tabular}

Dari Tabel 3.14 menunjukkan bahwa signifikansi efek, kecuali untuk kelembaban, curah hujan dan interaksi antara kovariat kontinu untuk model M12 dan M13. Berdasarkan tabel 3.14 diketahui bahwa transformasi memberikan efek cukup signifikan terhadap perubahan besaran 


\section{Jurnal Matematika, Statistika E Komputasi}

\section{Miftahuddin, Wanda Sri Noviana}

nilai parameter, seperti nilai intersep berubah dari 26.890 menjadi 28.181. Meskipun beberapa besaran parameter menunjukkan nilai yang dapat dikategorikan serupa.

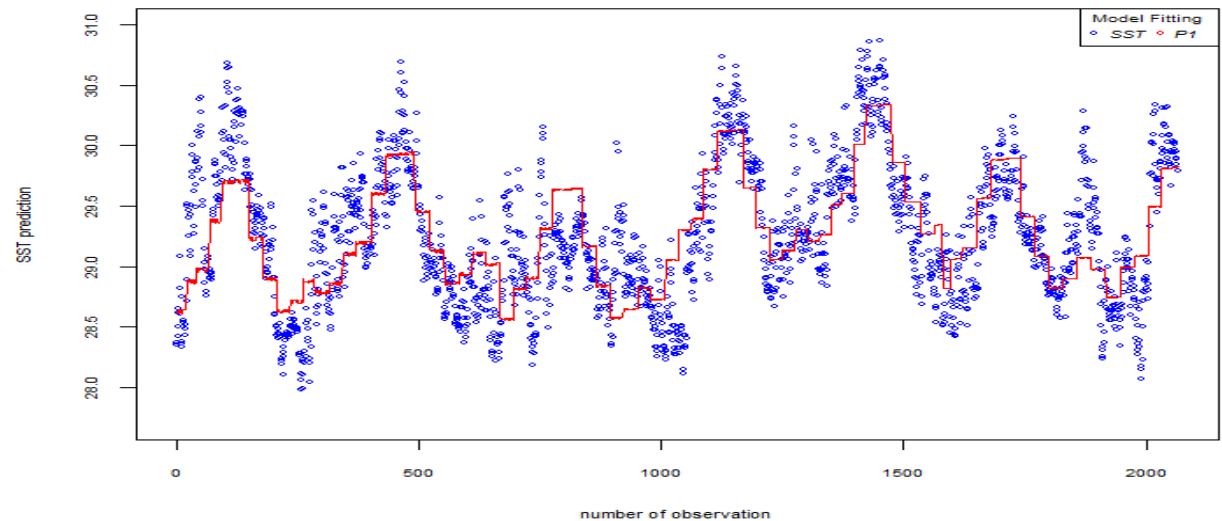

Gambar 3.5. Model M13 linier fitting untuk data SST

Bila kita mengamati fitting data SST antara model M12 dan M13 menunjukkan bahwa M13 lebih smooth dibandingkan model M12.

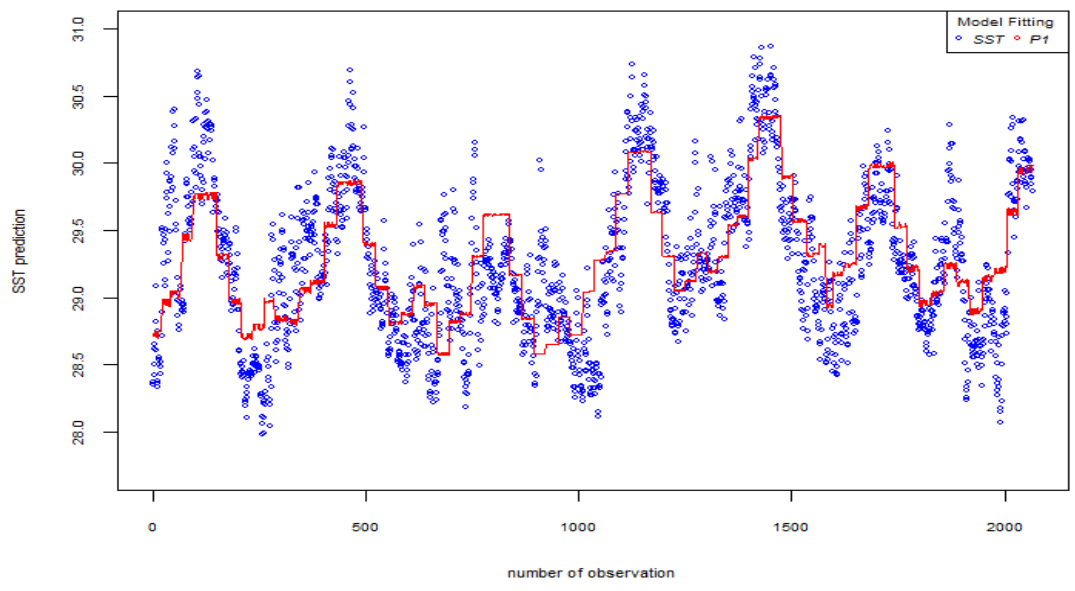

Gambar 3.6. Model M14 linier fitting untuk data SST

Dengan menggunakan model M14 dan M15 dengan koefisien korelasi antara Rho $=0.5-0.9$ diperoleh Tabel ANOVA sebagai berikut:

Tabel 3.15. Anova dari model M14 dan M15

\begin{tabular}{cllllll}
\hline \multicolumn{9}{c}{ M14 } & \multicolumn{5}{c}{ M15 } \\
\hline Parameter & numDF & F-value & p-value & numDF & F-value & p-value \\
Intercept & 1 & 8669221 & $<.0001$ & 1 & 9114365 & $<.0001$ \\
Temp & 1 & 158 & $<.0001$ & 1 & 132 & $<.0001$ \\
Month & 11 & 122 & $<.0001$ & 11 & 129 & $<.0001$ \\
Year & 6 & 64 & $<.0001$ & 6 & 59 & $<.0001$ \\
Humd & 1 & 0 & 0.6907 & 1 & 0 & 0.6939 \\
Rain & 1 & 0 & 0.9956 & 1 & 0 & 0.8369 \\
Temp:Humd & 1 & 1 & 0.3823 & 1 & 2 & 0.1682 \\
Temp:Rain & 1 & 0 & 0.8436 & 1 & 0 & 0.9440 \\
Humd:Rain & 1 & 1 & 0.3699 & 1 & 1 & 0.2526 \\
\hline
\end{tabular}




\section{Jurnal Matematika, Statistika \& Komputasi}

Miftahuddin, Wanda Sri Noviana

Dari Tabel 3.15 menunjukkan bahwa signifikansi efek, kecuali untuk variabel kelembaban, c urah hujan dan interaksi antara kovariat kontinu untuk model 14 dan M15. Berdasarkan tabel 3.15 diketahui bahwa transformasi memberikan efek cukup signifikan terhadap perubahan besaran nilai parameter, seperti nilai intercept dari 30.1343 menjadi 31.5010. Meskipun beberapa parameter menunjukkan besaran yang dapat dikategorikan serupa atau tidak mengalami perubahan berarti secara statistic untuk model M14 dan M15.

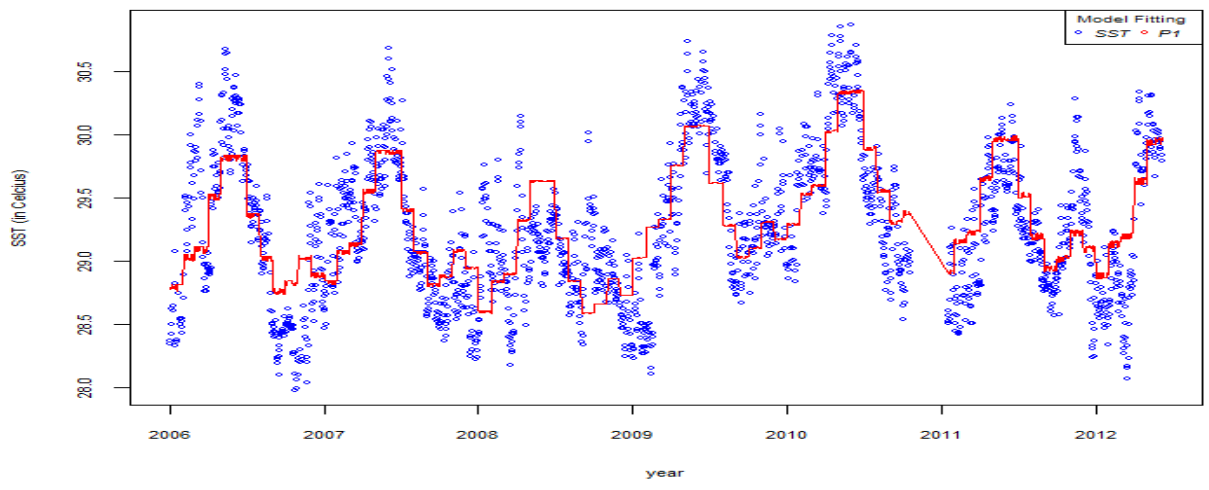

Gambar 3.7. Model M15 linier fitting untuk data SST

Gambar 3.7 menunjukkan M15 model fitting yang lebih smooth dibandingkan M14 model pada gambar 3.6. dan memiliki nilai AIC lebih kecil dibandingkan model M14. M15 model fitting ini lebih appropriate dibandingkan model M4 pada Gambar 3 yang masih memiliki efek autokorelasi.

\section{Kesimpulan}

Model linier fitting dengan kombinasi interaksi kovariat dan transformasi memberikan nilai $\mathrm{R}^{2}$ terbesar diantara perlakuan-pelakuan yang diberikan pada model yaitu dengan dan tanpa interksi, dengan dan tanpa transformasi, dengan dan tanpa centering kovariat, dan kombinasi antar perlakuan yang diberikan. Meskipun demikian, nilai efek kombinasi interaksi kovariat dan transformasi pada nilai $\mathrm{R}^{2}$ tergolong kecil (dibawah 0,5\%) yaitu memberikan perubahan besaran multiple $\mathrm{R}^{2}$ dan adjusted $\mathrm{R}^{2}$ masing-masing sebesar $0,31 \%$ dan $0,43 \%$. Hal ini menunjukkan bahwa kovariat waktu memiliki efek signifikan yang kuat pada model linier fitting untuk dataset SST.

Untuk kajian satu buoy diketahui bahwa year effect menunjukkan signifikansi puncak tertinggi terjadi pada tahun 2010 dan terendah tahun 2008. Sedangkan untuk month effect menunjukkan trend naik terjadi dari bulan Januari hingga Juni dan trend menurun dari bulan Juni hingga September. Selanjutnya, trend terus menaik kembali hingga November dan menurun pada Desember. Oleh karena itu, puncak month effect tertinggi terjadi pada bulan Juni dan terendah pada bulan September.

Untuk mendapatkan nilai optimal dari multiple $\mathrm{R}^{2}$ dan adjusted $\mathrm{R}^{2}$ serta nilai terkecil AIC maka autokorelasi menjadi perhatian utama pada perlakuan fitting guna mengatasi kompleksitas dataset SST.

\section{REFERENCES}

[1] Alvin C., \& G. Bruce S., 2008. Linear Models in Statistics. Second Edition. John Wiley \& Sons Inc., New York. 


\section{Jurnal Matematika, Statistika \& Komputasi}

\section{Miftahuddin, Wanda Sri Noviana}

[2] Clara D., Michael A., Shang P., \& Adam S., 2010. Sea Surface Temperature Variability: Patterns and Mechanisms. The Annual Review of Marine Science, Vol. 2, No. 1, 115-143.

[3] Friedrich A., Shang P., \& Julian P., 2009. Indian Ocean Circulation and Climate Variability. Reviews of Geophysics, Vol. 47, No. RG1002, 1-46.

[4] Gerald R., \& Mark J., 1998. Detecting Climate Signals in The Surface Temperature Record. Journal of Climate, Vol. 11, No. 4, 563-577.

[5] Grant B., 1985. Analysis of General Circulation Model Sea Surface Temperature Anomaly Simulations Using a Linear Model, Part I: Forced Solutions. Journal of The Atmospheric Sciences, Vol. 42, No. 21, 2225-2241.

[6] Hastie T., Tibshirani R., \& Friedman J., 2001. The Elements of Statistical Learning. Springer., New York.

[7] Hastie T., Tibshirani R., \& Friedman J., 2008. The Elements of Statistical Learning: Data Mining, Inference, and Prediction. Second Edition. Springer., New York.

[8] James G., Witten D., Hastie T., \& Tibshirani R., 2013. An Introduction to Statistical Learning. Springer., New York.

[9] Jan R., Bertrand M., \& Chris M., 2011. Global Warming and Local Dimming: The Statistical Evidence. Journal of The American Statistical Association, Vol. 106, No. 494, 452-464.

[10] Raymond H., Douglas C., G. Geoffrey V., \& Timothy J., 2010. Generalized Linear Models. Second Edition. John Wiley \& Sons Inc., New Jersey.

[11] Shang P., Clara D., Gabriel A., Jian M., Haiyan T., \& Andrew T., 2010. Global Warming Pattern Formation: Sea Surface Temperature and Rainfall. Journal of Climate, Vol. 23, No. 4, 966-986.

[12] Weisberg S., 2005. Applied Linear Regression, Third Edition. John Wiley \& Sons Inc., New Jersey. 